\title{
Kreativitas musik film Sang Pencerah
}

\author{
Ardy Aprilian Anwar', Arief Budiman², Zaini Ramdhan ${ }^{3}$ \\ 1,2,3 Universitas Telkom, Bandung, Indonesia
}

\begin{abstract}
ABSTRAK
Kualitas musik film layar lebar dan layar kaca di Indonesia telah memperdengarkan peningkatan baik walaupun masih banyak ditemukan penggunaan musik OST yang dominan sebagai musik filmnya. Dari fenomena tersebut, peneliti melakukan penelitian pada musik film Sang Pencerah yang digarap oleh Tya Subiakto pada tahun 2010 untuk melihat sudut pandang berpikir kreatifnya. Musik film ini juga mendapatkan penghargaan pada Festival Film Bandung 2011. Berangkat dari dorongan tersebut, kemudian peneliti merumuskan pertanyaan penelitian tentang bagaimana kreativitas musik film Sang Pencerah hingga bagaimana masa lalu Tya Subiakto (komposer) mempengaruhi kreativitas musik film Sang Pencerah. Penelitian ini termasuk ke dalam jenis penelitian dengan metode kualitatif interpretatif, melihat unsur-unsur nilai budaya dalam wujud musikal untuk dijabarkan secara tekstual dan ditemukan makna-makna objektif berupa hubungan musik dengan konten cerita dalam adegan-adegan film Sang Pencerah. Metode tersebut dilakukan dengan pemetaan sktruktur hubungan antara musik film Sang Pencerah dengan jalan cerita lalu membedahnya dengan literatur atau teori komposisi musik dan teori afektif musik. Setelah itu, untuk memperkuat hasil penafsiran interpretatif maka dilakukan wawancara dengan Tya Subiakto sebagai komposer utama musik film Sang Pencerah serta narasumber primer terkait untuk diolah dan dijadikan landasan interpretasi atau data pendukung. Setelah menemukan struktur musik dari aspek komposisi dan unsur afektif dan diperkuat dengan data wawancara, maka peneliti merumuskan hasil penelitian berupa hubungan cerita dengan kreativitas musik film pada film Sang Pencerah. Untuk memperkuat jawaban penelitian, peneliti membuat analisis perbandingan pada karya lain yang dibuat Tya Subiakto, sehingga menemukan karakteristik dan dasar-dasar berpikir dari bentuk musik pada proses merancang musik film Sang Pencerah.
\end{abstract}

Kata-kata Kunci: Musik film; proses; kreativitas; Tya Subiakto; film Sang Pencerah

\section{Sang Pencerah's film music scoring creativity}

\begin{abstract}
The quality of film music on the big screen in Indonesia has made good progress although there are still dominant of OST music as its film music. Researchers determining the music of the film Sang Pencerah which was worked on by Tya Subiakto in 2010 to see the perspective of his creative. Because of film's music also won an award at the Bandung Film Festival 2011, researcher formulated research questions about the creativity of Sang Pencerah's film music and how Tya Subiakto's past (composer) influenced the creativity of Sang Pencerah's film music. This research uses interpretative qualitative methods, looking at the elements of cultural values in musical form to be explained textually and found objective meanings in the form of music's relationship with story content and then dissecting it with theory of music composition and music affective theory. Interviews were conducted with Tya Subiakto as the main composer and primary resource person to be processed and used as a basis interpretation and supporting data. After discovering the structure of the musical composition, affective elements, then reinforced by interview data, the researcher formulated the results of the study in the form of the relationship of the story with the creativity of film music. Researcher made a comparative analysis of other works made by Tya Subiakto to discover the characteristics and basics of thinking from the form of music in the process of designing the film music of Sang Pencerah.
\end{abstract}

Keywords: Film scoring; process; creativity; Tya Subiakto; Sang Pencerah film

Korespondensi: Ardy Aprilian Anwar, S.Pd., M.Sn. Universitas Telkom. Jl. Telekomunikasi Dayeuhkolot Bandung 40257. Email: ardyapriliananwar@telkomuniversity.ac.id 


\section{PENDAHULUAN}

Musik film berkembang semakin pesat sesuai dengan perkembangan zaman. Awalnya, musik film memiliki fungsi menutupi gangguan suara proyektor yang keluar saat film diputar (Palmer \& Yorke, 2012). Musik film mengalami perkembangan fungsi ke arah yang lebih dominan dalam hal fungsi. Keberadaan musik film memiliki peran penting dalam membangun perasaan dan emosi penonton.

Musik film muncul setelah film bisu muncul di tahun 1920-an (Setiawan, 2017). Beberapa pendapat menyebutkan bahwa penciptaan musik film (terutama di Indonesia) disesuaikan dengan kebutuhan para pencipta film. Embie C. Noer berpendapat bahwa kreativitas musik film sangat bergantung pada kreativitas karya film. Noer menyatakan bahwa saat ini dunia perfilman sedang terjadi epigon ekstrim. Belum terlihat gejala yang signifikan adanya eksplorasi di kalangan sineas kita saat ini. Akibat dari hal tersebut berimbas pada elemen-elemennya, termasuk musik (C. Noer, 2018). Hal tersebut senada dengan yang diungkapkan oleh Dian Indri. Dian menyebutkan bahwa industri film di Indonesia belum terlalu menganggap musik film terlalu penting, padahal musik film memiliki efek bius (Indri, 2012).

Peranan musik memiliki tempat yang sama dengan gambar dalam film. Tetapi beberapa sineas dan produsen film di Indonesia tidak begitu menghiraukan unsur audio dalam filmnya. Bahkan dunia pertelevisian pun memposisikan musik sebagai unsur yang memiliki kekuatan besar dan berpengaruh pada program di dalamnya (Kurniawati, 2019). Kekuatan dan pengaruh musik memiliki variasi tersendiri tergantung dari pengalaman setiap individu (Swaminathan \& Schellenberg, 2015). Beberapa penelitian lain mengungkapkan pengaruh musik terhadap reaksi pendengar. Musik memiliki pengaruh cukup kuat untuk membangkitkan empat mekanisme tingkatan emosi dan perasaan (Juslin, Barradas, \& Eerola, 2015)

Di Indonesia, khususnya Kota Bandung, terutama di lingkungan Telkom University, Peminatan Multimedia (film), jumlah peminat film bertambah dari tahun ke tahun. Akan tetapi, karena mereka tidak berlatar dari pendidikan musik dan juga jasa pembuatan musik film yang orisinal termasuk dalam kisaran harga terbilang mahal, akhirnya mengambil jalan pintas dengan membubuhkan musik-musik "gratisan" dari internet pada karya-karya Tugas Akhir mereka. Hal tersebut juga tercermin pada karya-karya produser-produser sinetron di televisi-televisi nasional. Film-film televisi, sinetron, bahkan beberapa acara-acara talkshow mengandalkan musik-musik komersil dalam bentuk lagu sebagai stock untuk beberapa adegan secara 
yang diputar berulang-ulang karena kebutuhan mengejar target.

Kemajuan Musik Film di Indonesia tidak diikuti dengan baik oleh kemajuan dan perhatiannya pada musik filmnya. Penggunaan stok bahan rekaman masih terjadi hingga sekarang, misalnya pada film televisi (FTV) di kanal SCTV dan sinetron-sinetron dengan genre religi di INDOSIAR yang menjadikan lagu tertentu hingga $\pm 50 \%$ pada musik filmnya. Hal tersebut memberi kesan bahwa musik film di Indonesia belum dianggap hal yang begitu penting.

Melihat kondisi tersebut, penulis melihat beberapa aspek penentu kualitas musik film. Selain keahlian dan pengalaman, kreativitas menjadi landasan berpikir seniman musik film pada saat ia berkarya. Dengan demikian, target dari penelitian ini mengarah pada aspek-aspek penyebab kreativitas sebagai landasan berkarya seniman-seniman musik film. Jika Zulkarnaen mengatakan bahwa kreativitas merupakan proses analisis dari hal yang sudah ada sehingga melahirkan sesuatu dengan keunikan baru, maka tidak menutup kemungkinan jika kualitas musik film di Indonesia dapat dikembangkan lagi (Zulkarnain, 2013).

Dalam menentukan objek penelitian, penulis memilih film Sang Pencerah tahun 2010. Musik film Sang Pencerah dipimpin oleh Tya Subiakto sebagai komposer utama.
Musik film yang digarap oleh perempuan ini memiliki kolaborasi yang cukup dominan. Kolaborasi dengan waditra-waditra tradisional Jawa tersebut mendapatkan perhatian hingga penghargaan pada Festival Film Bandung 2011. Proses penelitian dilakukan dengan terlebih dahulu melakukan pengumpulan data terkait diri Tya Subiakto beserta data terkait Film Sang Pencerah. Teori yang digunakan diantaranya psikoanalisis (Freud, 2005) untuk menemukan hubungan masa kecil Tya pada kreativitasnya, struktur dramatik (Matthews, 1879) untuk memetakan bagian-bagian film, hingga hubungan musik pada reaksi afektif pendengar (Hevner, 1935) untuk membaca pengaruh emosional musik. Proses analisis dilakukan dengan mengumpulkan data, literasi, dan penjelasan langsung dari Tya Subiakto hingga menganalisis landasan kreatifnya dengan psikoanalisis. Data tersebut dijadikan landasan untuk membuktikan pembedahanpembedahan dalam struktur karya musik film Sang Pencerah, untuk kemudian ditemukan landasan dan proses kreatif musik film Sang Pencerah. Hasil dari penelitian ini dapat ikut berkontribusi mengembangkan keilmuan musik film di Indonesia.

\section{METODE PENELITIAN}

Karena dalam penelitian mengenai proses kreatif musik film Sang Pencerah ini tidak 
cukup hanya berdasarkan literatur secara tertulis saja, maka penjelasan mengenai data sebenarnya dari Tya Subiakto sangat diperlukan. Untuk itu, peneliti menerapkan penelitian kualitatif deskriptif interpretatif dengan pendekatan psikoanalisis. Penelitian dalam aspek musik berupa deskripsi interpretasi dalam menyimpulkan analisis pada pemahaman konseptual peneliti. Dengan demikian, peneliti berusaha menyampaikan gambaran yang jelas mengenai aspek-aspek dasar kreativitas Tya Subiakto berupa deskripsi hasil pengolahan penelitian. Proses wawancara terhadap Tya Subiakto serta tokoh-tokoh seniman musik film pun (Anggana, 2018; C. Noer, 2018; Wikagoe, 2018) dilakukan langsung untuk memperoleh data yang lebih valid.

Persiapan khusus yang dilakukan peneliti adalah dengan mengamati detail pribadi Tya Subiakto (data wawancara, penjelasannya di media sosial (video), hingga perjalanan kekaryaannya). Data yang diperoleh dari internet kemudian dielaborasi dan dikomparasi dengan sumber-sumber lainnya untuk mendapatkan validitas data. Data literatur yang mengkaji musik film dari buku, jurnal, tesis, hingga skripsi tak lupa dijadikan sumber data. Observasi dilakukan peneliti dengan cara pengamatan langsung terhadap audio visual film Sang Pencerah tahun 2010 yang diunggah oleh duasatu.com.
Analisis terhadap kreativitas dan realisasi gagasan dilakukan dengan pembedahan karya di awal, seperti spotting adegan-adegan benang merah sebagai dasar dan batasan penelitian. Kemudian dilakukan penjabaran musik pada adegan-adegan tersebut untuk menjelaskan landasan kreatif Tya Subiakto.

Teori yang digunakan dalam penelitian ini adalah salah satunya pembagian babak dalam film atau dramatic tension (Matthews, 1879) sebagai alat bedah struktur film, teori komposisi musik (Green \& Jones, 1974) untuk menjelaskan unsur-unsur pembentuk musik seperti melodi, akor, tangga nada, harmoni, tempo, irama, dan dinamika. Unsur afektif musik (Hevner, 1935) juga menentukan aspek afektif musik film Sang Pencerah hingga bahan kajian kreativitas Tya Subiakto dalam merancang musiknya. Pembedahanpembedahan tersebut menghasilkan kesimpulan bentuk musik berdasarkan struktur musik film. Setelah menemukan benang merah psikoanalisis (Freud, 2005) pada data diri Tya Subiakto peneliti menemukan relasi antara kreativitas musik film dengan hasil psikonalisis.

\section{HASIL DAN PEMBAHASAN}

Freud mengemukakan bahwa orang hanya didorong untuk menjadi kreatif jika mereka tidak dapat memenuhi kebutuhan secara langsung. Proses fisiologis Tya 


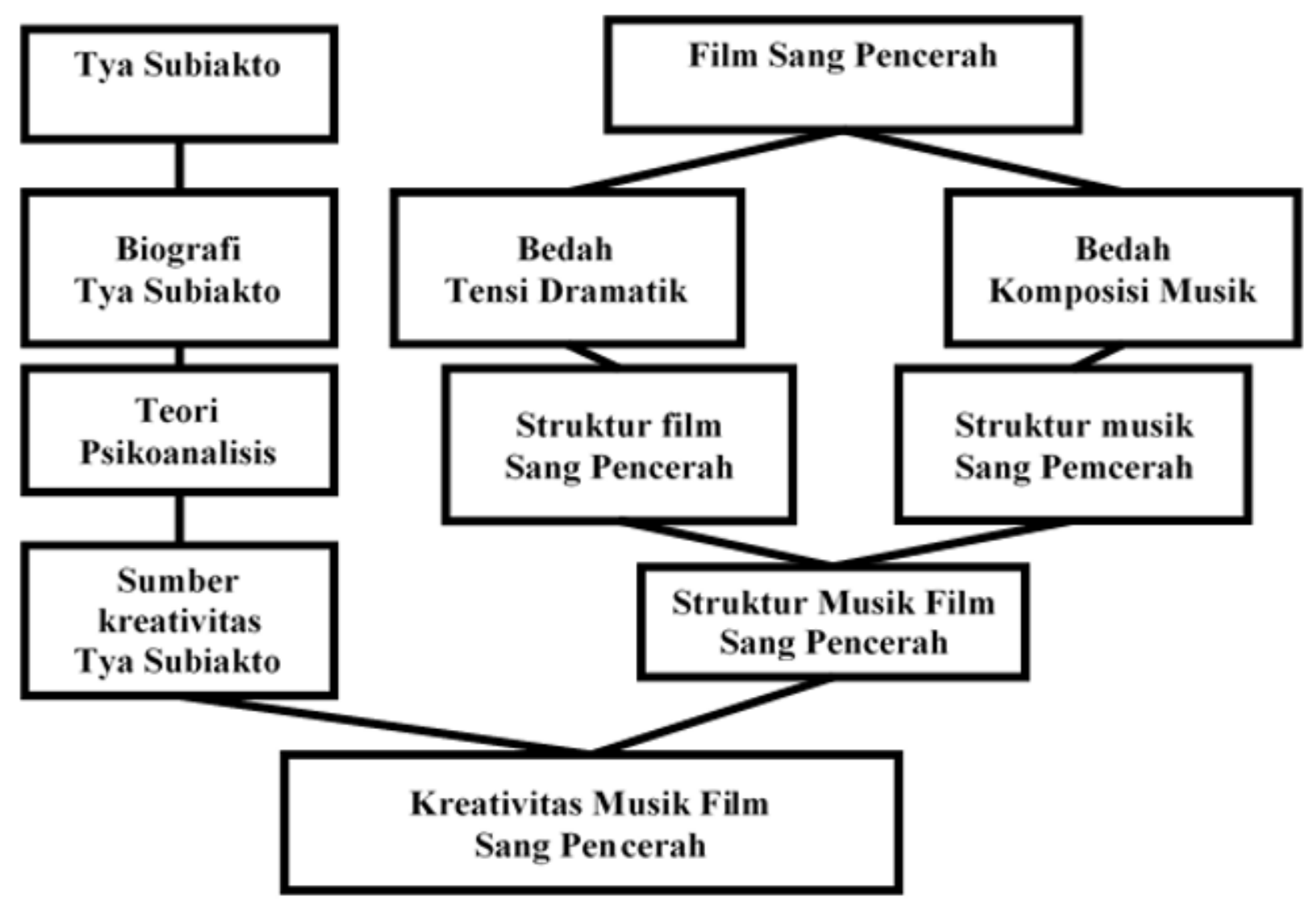

Sumber: Pribadi, 2018

Gambar 1 Alur Pikir Penelitian

Subiakto dalam berkomunikasi di usia emas ( \pm 5 tahun) mengalami keterlambatan. Akan tetapi kegelisahan tersebut direduksi dengan kreativitas yang muncul pada pemikiran ayahnya. Tya kecil didorong ayahnya untuk belajar bernyanyi agar keterlambatan tersebut bisa diupayakan teratasi. Upaya tersebut malah menunjukan keahlian bidang musik Tya yang lainnya. Akhirnya ayahnya memutuskan untuk melanjutkan studi vokalnya ke jenjang yang lebih serius.

Penjelasan dalam penelitian terhadap Tya kecil membuktikan bahwa cerita-cerita fiksi yang ia dapatkan dapat mempertajam musikalitasnya dengan didorong belajar musik oleh ayahnya yang menyebabkan pembentukan reaksi. Psikoanalisisnya memperlihatkan bahwa kreativitasnya berkembang dengan dorongan introjeksi sosok John Williams. Tya melakukan pertahanan diri dengan mengambil alih nilainilai dan standar John Williams positif maupun negatif untuk kemudian diinternalisasikan pada dirinya. Pada fase usia berikutnya, saat Tya beranjak lulus dari tingkat SMU, ayahnya meminta Tya melanjutkan studinya ke jurusan psikologi. Pada fase ini Tya menolak keinginan ayahnya dengan menekan impuls-impuls ego oleh superego, dengan kata lain menekan 
sesuatu yang tidak sesuai harapan, tahapan ini disebut represi. Tya melanjutkan tahap represi dengan memutuskan untuk tetap fokus di ranah bidang musik, tahap ini adalah fiksasi. Tya menyempurnakan keinginannya dengan proyeksi untuk tetap fokus pada film dengan memberikan atribusi komposer musik film pada komposer jingle iklan sebagai batu loncatan ego menuju hasratnya, superego.

Pembentukan reaksi tadi diperkuat dengan sublimasi pada alat musik organ dan para pengasuh di rumahnya sehingga memperbesar harapan untuk mewujudkan mimpinya. Hingga akhirnya saat mendapat tawaran perwujudan mimpinya, Tya melakukan regresi pada tekad yang pernah ia tumbuhkan saat kecil. Hasil analisis tersebut menjadi landasan kuat pengaruh masa kecil Tya Subiakto terhadap kreativitasnya pada musik film Sang Pencerah.

Penelitimelakukan pembagiansegmen yang berfungsi sebagai pengelompokan adegan atau sekuen. Film Sang Pencerah dipecah menjadi total 13 sekuen serta 70 adegan. Tercatat sekuen dengan adegan terbanyak adalah sekuen nomor 12 dengan jumlah 12 adegan dengan durasi 15 menit serta paling pendek adalah sekuen nomor satu dengan jumlah dua adegan dengan durasi sekitar dua menit delapan detik.

Peneliti telah meninjau ulang film tersebut dan mengumpulkan isyarat musik, elemen suara dan titik-titik tindakannya dalam satu garis waktu. Kesimpulan umumnya dapat dinyatakan bahwa film ini menampilkan keberadaan musik sekitar $90 \%$ dari total durasi film selama \pm 2 jam.

Pembedahan struktur film dengan teknik dramatic tension (Matthews, 1879) menghasilkan pembagian struktur film Sang Pencerah berdasarkan fase eksposisi, komplikasi, klimaks, resolusi, dan konklusi. Pembedahan musik dengan teknik komposisi menghasilkan struktur dan bentuk musik berdasarkan melodi, tempo, tangga nada, kadens, dinamika, dan lainnya. Pembedahan melalui dua teknik tersebut menghasilkan kesimpulan bentuk musik berdasarkan struktur film, atau struktur musik film.

Pembahasan musik dikategorikan ke dalam pembagian struktur film berdasarkan tensi dramatik. Hal ini dilakukan untuk efektivitas penelitian musik film yang berdurasi sekitar dua jam lebih. Analisis dilakukan pada musik film yang diciptakan berdasarkan struktur film sekaligus berdasarkan penerapan filosofis dari jenis instrumen yang dipilih.

Peneliti membagi pembabakan film berdasarkan sekuen-sekuen yang muncul pada film Sang Pencerah seperti pada tabel 1. Analisis berdasarkan pembagian-pembagian struktur dramatik membantu peneliti melihat perjalanan musik secara keseluruhan film. Berdasarkan hasil analisis, peneliti menyimpulkan perubahan musik sebagaimana dalam Tabel 2. 
Tabel 1 Struktur Tensi Dramatik film Sang Pencerah

\begin{tabular}{cccc}
\hline Babak Awal & Babak Tengah I & Babak Tengah II & Babak Akhir \\
\hline Eksposisi & & & \\
Komplikasi & Komplikasi & Komplikasi & Komplikasi \\
Klimaks & Klimaks & Klimaks & Klimaks \\
Resolusi & Resolusi & Resolusi & Resolusi \\
& & & Konklusi \\
\hline
\end{tabular}

Sumber: Hasil Penelitian, 2015

Tabel 2 Struktur Musik film Sang Pencerah secara keseluruhan

\begin{tabular}{cc}
\hline Struktur Dramatik & Struktur Musik \\
\hline Eksposisi & Kolaborasi \& Instrumentasi penuh \\
Babak awal & Penggunaan melodi tema Mars Muhammadiyah \\
Babak tengah I & Penggunaan melodi baru \\
Babak tengah II & Penggunaan soundtrack \\
Babak akhir & Pemusatan musik pada konflik \\
Konklusi & Kolaborasi \& Instrumentasi penuh \\
\hline
\end{tabular}

Sumber: Hasil Penelitian, 2015

Berdasarkan hasil analisis tersebut, peneliti menyimpulkan analisis secara deskriptif pada paragraf di bawah. Kesimpulan ini berdasarkan aspek dalam musik seperti spotting, tempo, birama, instrumen, harmoni, tangga nada, melodi, dan lainnya, walaupun kenyaringan sinyal suara dan irama musik berperan penting terhadap ekspresi emosi (Liu, Zhao, \& Hua, 2015). Peneliti juga membandingkan musik film Sang Pencerah dengan musik film karya terbaik Tya yang lainnya seperti "Rudy Habibie" tahun 2016 untuk menemukan karakter karakter musik film Tya Subiakto.

Terdapat beberapa landasan Tya Subiakto menempatkan musik-musiknya pada setiap adegan (spotting). Pertama, Tya melihat adegan-adegan yang berkesinambungan dan memungkinkan untuk dijadikan satu kesatuan atau diikat dengan satu bentuk musik. Kedua, Tya melihat adegan dengan dialog yang menurut Tya dan sutradara dirasa kurang memberikan penekanan dramatis, sehingga dibuatkan musik yang berfungsi untuk menutupi kekurangan tersebut dan memambah penekanan dramatis pada dialognya. Terakhir, Tya menempatkan musiknya berdasarkan konten adegan, mengacu pada kebutuhan tensi dramatis. Dengan kata lain, Tya memberikan musik pada adegan yang akan sempurna secara dramatis jika diberikan musik.

Tempo dalam musik memberikan perubahan sikap pada pendengarnya. Selain 
Berdasarkan hasil analisis tersebut, peneliti menyimpulkan analisis secara deskriptif pada paragraf di bawah. Kesimpulan ini berdasarkan aspek dalam musik seperti spotting, tempo, birama, instrumen, harmoni, tangga nada, melodi, dan lainnya, walaupun kenyaringan sinyal suara dan irama musik berperan penting terhadap ekspresi emosi (Liu, Zhao, \& Hua, 2015). Peneliti juga membandingkan musik film Sang Pencerah dengan musik film karya terbaik Tya yang lainnya seperti "Rudy Habibie" tahun 2016 untuk menemukan karakter karakter musik film Tya Subiakto.

Terdapat beberapa landasan Tya Subiakto menempatkan musik-musiknya pada setiap adegan (spotting). Pertama, Tya melihat adegan-adegan yang berkesinambungan dan memungkinkan untuk dijadikan satu kesatuan atau diikat dengan satu bentuk musik. Kedua, Tya melihat adegan dengan dialog yang menurut Tya dan sutradara dirasa kurang memberikan penekanan dramatis, sehingga dibuatkan musik yang berfungsi untuk menutupi kekurangan tersebut dan memambah penekanan dramatis pada dialognya. Terakhir, Tya menempatkan musiknya berdasarkan konten adegan, mengacu pada kebutuhan tensi dramatis. Dengan kata lain, Tya memberikan musik pada adegan yang akan sempurna secara dramatis jika diberikan musik.

Tempo dalam musik memberikan perubahan sikap pada pendengarnya. Selain perubahan perilaku dan fisiologis pada otot, tempo dalam musik memberikan dampak pada denyut jantung (Kim, Strohbach, \& Wedell, 2019). Tya mengaku bahwa dirinya selalu mengikuto irama dari penyuntingan gambar dalam menentukan tempo (Subiakto, 2018). Hal tersebut membantu pembentukan kerangka nada dalam melodi pada karya musik. Proses ini harus dilakukan sesering mungkin untuk menemukan elemen yang muncul dalam beat sepanjang film, itulah sebabnya tempo dalam musik film sering berubah-rubah. Dari hasil analisis, tempo yang digunakan Tya pada musik film Sang Pencerah berkisar antara 60 BpM hingga $120 \mathrm{BpM}$ dengan dominasi penggunaan tempo pada kisaran 100BpM kebawah. Contoh, pada bagian plot sekuen tentang pertumbuhan masa kecil Darwis (Ahmad Dahlan kecil), Tya menggunakan tempo 80BpM dengan dasar berpijak pada durasi dari setiap shot ke shot gambar.

Birama (satuan kelompok ketukan) yang muncul pada musik-musik di film Sang Pencerah yaitu 4/4, 3/4, 6/8, dan birama bebas (rubato). Sebanyak hampir $80 \%$ dari total musik film Sang Pencerah menggunakan birama 4/4, sisanya menggunakan birama ketukan ganjil (3/4 dan 6/8). Dari hasil analisis, dapat ditarik kesimpulan bahwa Tya menerapkan birama ganjil di setiap adegan kebersamaan 
tokoh utama film (Ahmad Dahlan) dengan pasangannya (Siti Walidah) dalam film Sang Pencerah, atau di setiap penggunaan instrumen Harpa. Hal tersebut berdasarkan pada teknik permainan ornamentasi tiga nada pada akor dari instrumen Harpa dan kelembutan alunan irama sesuai dengan kelembutan karakter Siti Walidah. Penggunaan irama genap didasarkan pada tensi adegan yang memiliki nuansa beraksen jelas dan pasti.

Tya mengatakan bahwa tidak ada aturan khusus pemilihan instrumen pada musik film, karena semuanya tergantung pada kebutuhan komposer tentang sejauh mana ia memiliki pengharapan suatu rasa yang ingin dimunculkan dari musik tersebut. Selama ini, Tya mengacu pada musik-musik film dari Barat yang pada umumnya menggunakan orkestrasi sebagai pelengkap sajian musik filmnya (Subiakto, 2018). Pada film Sang Pencerah, Tya menggunakan orkestrasi yang disisipi dengan instrumen yang lebih spesifik untuk mengindikasikan tokoh dan tempat yang dimunculkan di film tersebut. Contohnya bunyi dari instrumen solo Biola untuk mengindikasikan tokoh Ahmad Dahlan. Instrumen tersebut menurut Tya lebih mampu menginterpretasi perasaan sedih, putus asa, iba, dan lainnya yang diperankan oleh tokoh Ahmad Dahlan. Selain itu, alasan utama Tya menggunakan solo Biola pada beberapa musik film Sang
Pencerah adalah karena Ahmad Dahlan adalah sosok yang pandai memainkan Biola, yang ia dapat dari teman Portugisnya. Instrumen lain pun ikut berperan mengindikasikan karakter dalam film Sang Pencerah, seperti instrumen Harpa untuk karakter Siti Walidah karena kelembutannya, waditra Rebab untuk karakter para Kyai karena kemagisan dan kemistisannya, instrumen Rebana untuk mengindikasikan nuansa religi Islam, hingga waditra Gamelan, Suling, Gambang untuk mengindikasikan kota Yogyakarta.

Dalam dunia psikologi, kaitan erat antara unsur musik harmoni dan melodi dengan respon emosi bukan merupakan hal baru (Liu et al., 2015). Harmoni dalam film Sang Pencerah memperlihatkan tingkat kompleksitas harmoni yang tinggi untuk menghadirkan kesan sedih dan dramatis, harmoni dengan kompleksitas sederhana memunculkan perasaan bahagia, dan harmoni dengan kompleksitas disonan memunculkan kesan permasalahan, kerumitan, ketakutan, hingga kemarahan. Dari hasil analisis, film Sang Pencerah dominan menggunakan jenis akor minor, bahkan pada beberapa plot, Tya menghadirkan disonansi untuk menambah kesan rumit yang tercermin dari film ini.

Tya membuatkan konsep karya musik film Sang Pencerah dengan mengangkat lagu Mars Muhammadiyah sebagai melodi tema. Tya menggunakan potongan motif melodi awal lagu 


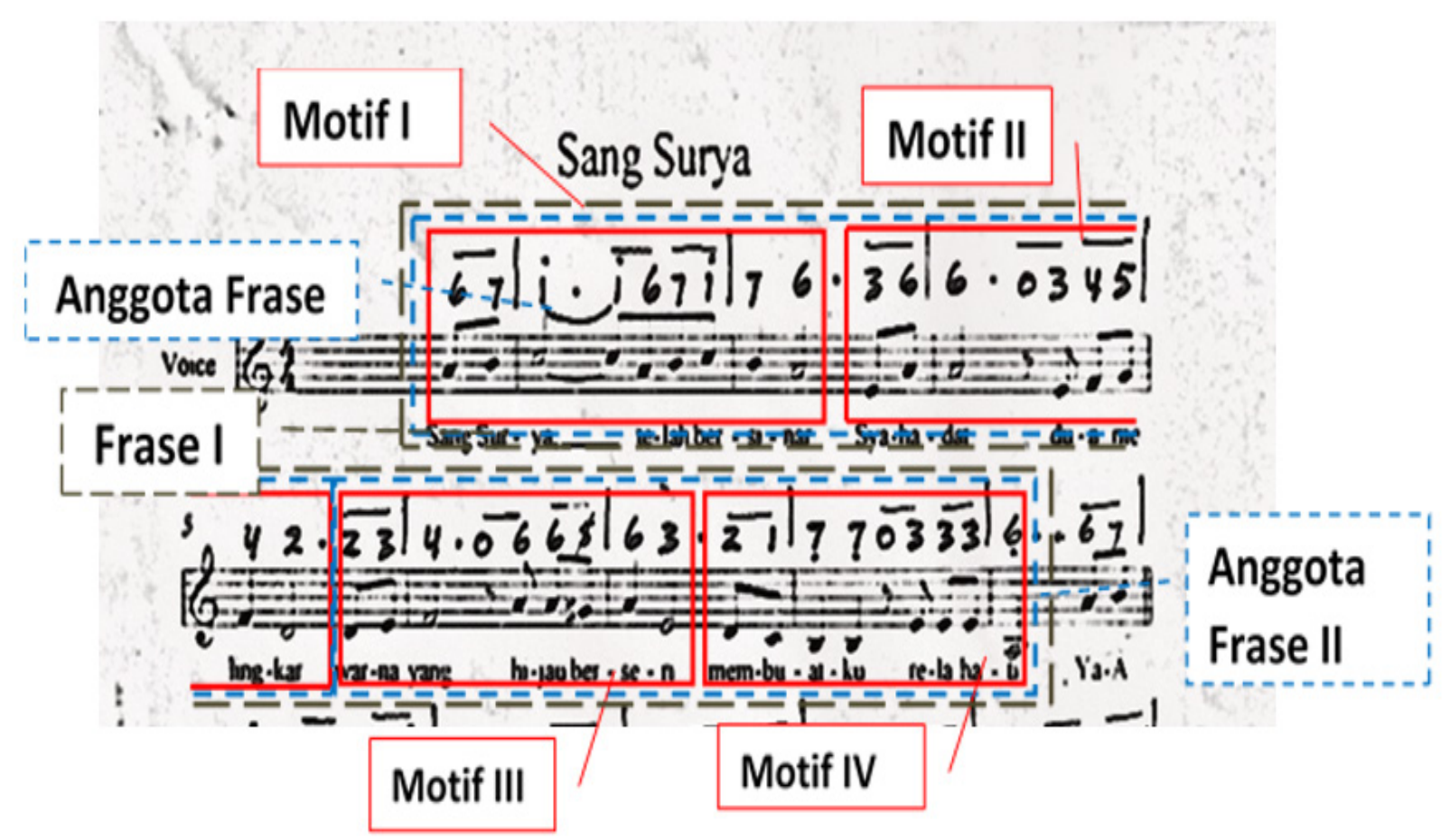

Sumber: Pribadi, 2018

Gambar 2 Pembagian bentuk kalimat lagu Sang Surya (Mars Muhammadiyah)

seperti pada gambar 2 .

Konsep melodi tema tersebut disetujui oleh sutradara dan produser film. Potongan motif meloditersebut seolahmemilikifungsimeditatif, hingga beberapa audiens mengingat film Sang Pencerah dengan hanya mendengarkan Mars Muhammadiyah, atau sebaliknya, mengingat lagu Mars Muhammadiyah ketika menonton film Sang Pencerah. Keberadaan melodi vokal secara verbal maupun nonverbal memiliki dampak terhadap emosi. Dalam penelitiannya tentang peran melodi sebuah lagu terhadap rasa emosi, anu mengatakan bahwa melodi mampu menghasilkan berbagai model emosi dengan tingkat generalisasi yang tinggi (Beveridge \& Knox, 2018).
Musik pada film Sang Pencerah hampir keseluruhan menggunakan tangga nada minor (diawali dengan kunci minor). Tangga nada mayor hanya terdapat dalam adegan pernikahan Ahmad Dahlan, Semangat AlMa’un, dan Perdamaian Ahmad Dahlan dengan Kyai Penghulu. Penggunaan jenis tangga nada yang Tya terapkan dalam musiknya adalah berdasarkan prinsipnya, bahwa setiap komposer musik film dapat dengan bebas menginterpretasikan nuansa dengan tangga nada apapun.

Dinamika pada musik film Sang Pencerah dapat diukur dengan menentukan tingkat kenyaringan atau intensitas volume musik. Kenyaringan musik disesuaikan dengan fungsi 
awal dari musik tersebut, jika fungsinya membantu tensi dramatis adegan, maka volume keseimbangan suara yang diatur adalah volume musik yang berada di bawah volume dialog, seperti pada adegan dialog Ahmad Dahlan dengan istrinya (durasi 01:10:00). Sebaliknya, jika musik berfungsi untuk membantu kekurangan dalam dialog, maka volume musik berada di atas volume dialog, seperti pada adegan dialog Ahmad Dahlan dengan muridnya (durasi 01:00:13). Dinamika musik juga diatur berdasarkan kebutuhan nuansa adegan, seperti perubahan dinamika pada adegan penghancuran Langgar Kidul milik Dahlan (durasi 00:40:00 - 00:45:00). Dengan demikian, dapat disimpulkan bahwa yang menjadi acuan Tya dalam menentukan dinamika pada musik film Sang Pencerah adalah fungsi dari musik film tersebut.

Film Sang Pencerah termasuk dalam jenis film kategori drama, historikal biografi epos, film drama dengan alur menceritakan sejarah perjalanan perjuangan seseorang yang diambil dari kisah nyata. Musik dalam film Sang Pencerah diawali dengan bentuk musik yang mencekam. Penahanan nada rendah tunggal menimbulkan kesan penuh misteri. Penambahan waditra Suling yang digabung dengan suara lantunan ayat suci Al-Quran surat Yasin untuk mengindikasi tempat dan kesan religius, dengan demikian suara pada bagian ini berfungsi naratif atau menjelaskan. Tya menciptakan berbagai bentuk musik pada film Sang Pencerah berdasarkan konteks dari adegan-adegan yang telah disepakati untuk dibubuhi musik. Dasar dari konteks adegan kemudian menjadi referensi Tya untuk membentuk beberapa unsur dalam komposisi musik. Secara keseluruhan, film Sang Pencerah memiliki karakter musik yang ekspresif. Berdasarkan konvensi musik film, Tya selalu menghadirkan tensi dramatis pada setiap musik yang ia ciptakan untuk adeganadegan kegagalan Ahmad Dahlan. Kombinasi dinamika kresendo, gesekan biola yang dominan menggunakan teknik slide dan vibrato, progresi kadens akor minor, penggunaan tempo rubato, dan melodi dengan durasi panjang mampu merepresentasikan konteks dari adegan-adegan pada film Sang Pencerah.

Sajian komposisi musik pada film Sang Pencerah karya Tya Subiakto secara garis besar merupakan dominasi orkestrasi diatonis dengan memainkan motif melodi Mars Muhammadiyah (Sang Surya). Bentuk musik lain yang muncul adalah musik tradisional Jawa dengan waditra Suling, Gambang, Siter, nyanyian Tembang, dan seperangkat Gamelan Jawa yang selalu dilapisi dengan orkestrasi. Nilai budaya yang digambarkan pada musik film akan mempertegas nilai-nilai kearifan lokal masyarakat (Hidayat, Rosidah, Retnasary, \& Suhadi, 2019). Berdasarkan naratif musik 
film, Tya secara konsisten menggunakan unsur musik tradisional Jawa dan instrumeninstrumen yang identik dengan nuansa Islam untuk menggambarkan tempat dan konten permasalahan. Bahkan pada beberapa adegan seperti pertemuan Dahlan dengan Budi Utomo, adegan suasana Keraton dan lainnya, musikmusik tradisional tersebut muncul tanpa diiringi atau berkolaborasi dengan orkestrasi. Bagi Tya, proses mencampurkan kedua segmen musik (tradisional dengan orkestra) merupakan hal yang sangat sederhana. Proses kombinasi tersebut dilakukan dengan mendahulukan musik tradisional, kemudian orkestrasi dibuat setelahnya dengan menyesuaikan pada hasil rekaman musik tradisional yang telah ada.

Penulis melakukan pembagian analisis musik film Sang Pencerah dengan melakukan breakdown sekuen. Musik film dibagi menjadi 13 cue berupa karya skoring musik film utuh dan beberapa dramatic tension berupa musikmusik dengan fungsi ilustrasi serta song track.

Sekuen pembuka film Sang Pencerah diawali dengan narasi-narasi singkat mengenai sejarah perkembangan Islam tahun 1868 di Kauman, Yogyakarta. Di bagian ini, Tya memberikan nada rendah panjang. Musik tersebut memberikan identitas atau karakter film tersebut. Sebelum masuk ke dalam cerita, penonton telah menerima informasi mengenai gambaran besar cerita film melalui musik.
Tempo lambat dalam musik ini menimbulkan kesan sedih, misterius, horor, dan semacamnya. Bunyi nada tunggal panjang mengisyaratkan ketidakjelasan atau merupakan suatu permulaan. Pitch rendah menyampaikan suatu kondisi yang mencekam. Dalam bagian musik lainnya, terdapat dua nada dengan interval setengah yang berbunyi secara bersamaan sehingga menimbulkan ketegangan pada frekuensi nada atau disonan. Ketegangan tersebut memunculkan perwujudan atas makna dalam cerita adegan film Sang Pencerah. Musik pada bagian ini berfungsi sebagai penghubung sekaligus sebagai pintu masuk berjalannya cerita film. Musik bagian ini yang berfungsi sebagai bridging cue ditandai dengan masuknya timpani dan cymbal yang dimainkan dengan teknik roll dengan dinamika kresendo.

Pada sekuen pembuka yang kedua, hasil analisis menunjukkan bahwa cue-cue berupa instrumentasi rebana terdapat pada dua adegan tentang semangat perjuangan Ahmad Dahlan dan juga pada satu adegan tentang keberangkatan Ahmad Dahlan untuk Haji. Pemilihan instrumen rebana terkait dengan mengisyaratkan keIslaman yang erat dengan Ahmad Dahlan. Hal tersebut mengacu pada kebudayaan rebana pada penggunaannya untuk melantunkan kasidah dan hadroh pada pertunjukkan-pertunjukkan Islami. Tya mencoba menggabungkan beberapa adegan dalam sekuen eksposisi dengan menggunakan 
musik sebagai media penghubung suasana, waktu, tempat, dan kejadian yang terputus oleh shot. Walaupun musik telah usai, Tya berusaha mempertahankan suasana eksposisi dengan memberinada panjang sebagai penghubung yang ditempatkan di setiap jeda antara plot ke plot. Pada fase eksposisi Tya masih menggunakan instrumen orkestra sebagai instrumentasi dasar yang berfungsi untuk iringan atau pun berperan utama dalam memainkan melodi tema.

Pada beberapa adegan, Tya membuat dan memperdengarkan teknik pedal point. Seperti yang telah diungkapkan pada pembahasan lengkap bahwa komposer sering kali menggunakan melodi dengan nada-nada panjang untuk membuat kesan penuh harapan, menghela hingga menahan nafas sejenak untuk merasakan sensasi dramatis. Selain itu, penggunaan nada panjang pada nada alas (bass) yang terdapat pada musik ilustrasi untuk adegan-adegan eksposisi ini selain memberikan kesan mistis, penuh misteri, dan suasana mencekam, juga dapat jadi penahan mood suasana permasalahan yang timbul pada fase eksposisi.

Tya menggunakan instrumen harpa pada karakter istri Ahmad Dahlan. Meskipun demikian, Tya masih menerapkan sistem nada panjang yang diterapkan pada sistem nada pendek walaupun berupa petikan-petikan instrumen harpa yang konstan pada beberapa nada. Instrumen yang digunakan oada cue ini adalah harpa dan flute. Instrumen flute dipilih karena memiliki beberapa karakter seperti lembut, halus, anggun, jernih, dan berangin (menyejukkan). Dengan demikian, pemilihan instrumen pada sekuen karakter ini cukup beralasan. Tya menggunakan instrumentasi harpa dalam fungsi indikatif untuk mengiringi setiap sekuen karakter istri Ahmad Dahlan dengan alasan karena harpa bersifat lembut. Cue-cue yang digunakan memiliki struktur yang cukup berbeda antara cue satu dengan yang launnya, namun Tya tetap konsisten dalam penggunaan instrumentasi harpa. Harpa memiliki karakter bunyi yang lembut, jernih, cemerlang, berkilau, mengalir, dan memercikkan (Symphonic Library, 2017). Karakter tersebut yang diambil Tya sebagai alasan penggunaan instrumen harpa untuk cue karakter Siti Walidah yang mempesona dan masih bersih.

Cue musik film pada sekuen persiapan haji Ahmad Dahlan menggunakan teknik mendahulukan cue musik daripada adegan atau sound bridge. Teknik ini bertujuan untuk memperhalus perpindahan adegan atau shot dan juga menghubungkan kedua adegan dengan mood yang sama (Pratista, 2017). Kedua adegan tersebut adalah adegan dialog Ahmad Dahlan dengan gurunya dan adegan persiapan keberangkatan Ahmad Dahlan untuk haji. 
Kedua adegan tersebut juga memiliki hubungan mood tentang keinginan Darwis untuk pergi haji. Walaupun Tya membuatkan musik penjembatan adegan, tetapi Tya memberikan perbedaan struktur pada musik tersebut sesuai dengan perpindahan shot.

Selain pada bagian-bagian awal, melodi lagu Sang Surya kembali muncul pada menit 09:11 dalam satu motif, tepatnya pada saat adegan Ahmad Dahlan membuktikan hasil perjuangannya mempelajari Bahasa Arab. Tya memunculkan melodi ini lagi-lagi untuk menekankan dramatisasi atas hasil kerja keras Ahmad Dahlan dalam mencari ilmu Islam lebih dalam.

Cue ini merupakan musik pertama yang mengandung instrumen solo biola di dalamnya. Menurut pengumpulan data dari berbagai sumber, K.H. Ahmad Dahlan adalah seorang kyai yang juga pandai memainkan alat musik biola. Oleh karena itulah Tya menggunakan solo biola pada sekitar $60 \%$ musik filmnya untuk merepresentasikan sosok Ahmad Dahlan.

Sekuen selanjutnya berisi adegan-adegan perjalanan Ahmad Dahlan ke Mekkah, kaleidoskop pencarian ilmu agama di Mekkah hingga kepulangan Ahmad Dahlan kembali ke Kauman. Pola permainan cue ini dimulai oleh instrumen perkusif dan nada tunggal dari ansambel kontrabas dan ansambel selo. Tya kembali mencoba membangun nuansa mencekam meskipun adegan yang muncul dalam gambar memperlihatkan sebuah perpisahan kepergian Darwis ke Mekkah. Tidak seperti adegan-adegan perpisahan lain pada umumnya yang menggunakan musik dengan nuansa sedih atau haru, Tya mempertahankan tema perjuangan yang di emban oleh Ahmad Dahlan ke dalam bentuk musik yang bernuansa tegar dan patriotisme. Setelah melodi tema Sang Surya berakhir, musik dilanjutkan pada bagian pengembangan. Tya membuat pengembangan melodi baru.

Sekuen berlanjut pada masa-masa pernikahan Ahmad Dahlan dengan istrinya Siti Walidah. Seperti halnya pada sekuen karakter Siti Walidah sebelumnya, Tya menggunakan tonalitas Mayor pada nuansa musik tersebut dengan maksud memberikan kesan kebahagiaan. Tya menerapkan musik ini untuk mewujudkan rasa bahagia atas pernikahan tersebut. Penggunaan instrumen Obo dengan karakter bunyi menyayat hati, menambah kedalaman kebahagiaan yang diceritakan pada sekuen tersebut. Cue ini ditutup dengan musik berkesan mencekam dengan sedikit permainan solo biola. Tya melakukan hal tersebut untuk menghubungkan dua suasana yang berbeda sekaligus, dari kebahagiaan menuju kesedihan. Dengan demikian, Tya menjalankan prinsip fungsi musik film sebagai pemindah adegan secara halus dengan suasana yang berbeda 
sekalipun.

Pada sekuen berikutnya, Tya memiliki alasan tersendiri memilih ilustrasi gamelan untuk mengisyaratkan karakter Sultan Hamengkubuwono. Salahsatunya adalah karena kemutakhiran teknologi material (dalam bidang musik) pada set di waktu adegan tersebut dalam teknologi tertinggi ada pada logam, yang kemudian digunakan di permusikkan kerajaan (Subiakto, 2018). Dapat disimpulkan bahwa penggunaan ilustrasi musik gamelan dapat menunjukkan kesan keagungan, kekuasaan, tradisi, istana, dan keraton. Selain itu, gamelan juga dipergunakan untuk menggambarkan karakter Sultan Hamengkubuwono sebagai seorang raja. Adegan ini dimulai dengan musik kombinasi orkestra dengan sentuhan waditra atau instrumen gamelan Jawa sebagai penegas karakter Sultan sekaligus penjelas tempat (Yogyakarta) dalam fungsi naratifnya.

Musik dengan melodi tema Sang Surya kembali hadir dengan bentuk nuansa patriotis pada sekuen perjuangan Ahmad Dahlan saat mencari kebenaran arah kiblat sholat. Bentuk musik yang digunakan untuk sekuen ini bercorak ketegangan yang didukung oleh penekanan motif berulang dan penegasan tempo oleh timpani dan tamborin. Adegan lainnya dalam sekuen ini, ketika Ahmad Dahlan melakukan perjalanan ke Bantul dengan menggunakan kereta api, merupakan salah satu dari empat adegan yang dibubuhkan tembang pada musik ilustrasinya. Tiga sisanya adalah tembang yang dinyanyikan oleh laki-laki (00:02:08), berikutnya dinyanyikan oleh perempuan (00:31:43), dan yang terakhir dinyanyikan oleh mertua Dahlan pada saat Langgar Kidul Dahlan dihancurkan (00:43:51) yang memiliki fungsi ganda, yaitu sebagai ilustrasi dan sebagai efek suara.secara keseluruhan, musik pada bagian ini dibagi menjadi tiga bagian. Bagian pertama, melodi tema dimainkan dengan gaya musik iringan yang menunjukkan kesan resah, perjuangan, dan konflik, yang salah satunya menggunakan motif melodi dengan teknik repetisi atau pengulangan. Bagian kedua terdapat pengulangan tema melodi ke permulaan, juga terjadi perpindahan nada dasar yang sekaligus berfungsi sebagai pemisah antar bagian.

Tidak seperti dualitas-dualitas yang terdapat dalam cue musik film sebelumnya, dualitas pada cue sekuen perjuangan Dahlan dalam meluruskan arah kiblat muncul dengan kontras. Terjadi perbedaan yang jelas dalam satu kesatuan pada irama yang digunakan antar instrumen. Perbedaan tersebut terdapat pada irama melodi tema Sang Surya yang dimainkan dengan irama dua kali lebih lambat dari irama yang sebenarnya. Akan tetapi tidak demikian halnya dengan yang terjadi pada iringan yang dimainkan oleh instrumen viola, dia memainkan 
melodi dengan irama notasi bernilai 1/16, irama yang cukup cepat untuk tempo 100 BpM. Dari perbedaan dualitas tersebut, terdapat makna simbolik yang dapat ditafsirkan. Pertama, permainan melodi dengan irama dua kali lebih lambat mengisyaratkan kebiasaan-kebiasaan (arah kiblat) yang memang telah dijalankan oleh masyarakatnya hingga menjadi karakter. Sedangkan permainan iringan melodi dengan irama cepat mengisyaratkan keresahan Dahlan dalam menanggapi keadaan tersebut.

Pada fase komplikasi tahap kedua, Tya memunculkan melodi tema baru seiring dengan kemunculan masalah baru. Melodi tema ini disajikan denan bentuk musik patriotis untuk mengiringi sekuen gambaran singkat perubahanperubahan budaya yang terjadi saat masuknya bangsa Portugis dan bangsa penjajah lainnya. Melodi tema ini menyatukan dua sekuen sekaligus dengan sekuen gambaran singkat perjalanan haji Ahmad Dahlan untuk kedua kalinya. Melodi tema baru juga digunakan pada saat adegan dialog intim antara Ahmad Dahlan dengan istrinya.

Kerumitan terakhir pada bagian ini terdapat pada adegan saat Ahmad Dahlan bergabung dengan organisasi Budi Utomo dan Kweekschool. Pada bagian ini Tya membuat kesan yang berbeda dengan kesankesan permasalahan sebelumnya. Kali ini Tya menjadikan permasalahan menjadi tenang untuk menyesuaikan dengan sikap Ahmad Dahlan yang selalu tenang atas apa yang dia lakukan, Tya menganggap bahwa kerumitan pada adegan ini justru merupakan titik awal pencerahan yang akan dimunculkan Dahlan. Tya memberikan nuansa tenang dengan menggunakan musik khas Yogyakarya, yaitu Siteran yang merupakan kombinasi Siter dengan Gambang dengan laras Slendro dan dinamika lembut. Sedangkan pada adegan bergabungnya Dahlan dengan Kweekschool, Tya memberikan nuansa orkestrasi dan harmoni ala Barat. Dua adegan berbeda dengan warna musik berbeda. Penjelasan ini dapat dilihat pada Tabel 3 dan Tabel 4.

Tabel 3 Struktur musik pada sekuen-sekuen fase komplikasi pertengahan I bagian I

\begin{tabular}{clc}
\hline Tahap Komplikasi & \multicolumn{1}{c}{ Instrumen } & $\begin{array}{c}\text { Tempo \& } \\
\text { Irama }\end{array}$ \\
\hline Pertengahan & - Siter & $\pm 125 \mathrm{BpM}$ \\
I (gambaran & - Gambang & \\
bergabung Budi & - Suling & \\
Utomo) & & \\
\hline Pertengahan & - Intrumentasi & $\pm 60 \mathrm{BpM}$ \\
I (gambaran & gesek & \\
bergabung & - Oboe & \\
Kweekschool) & - Harpa & \\
\hline
\end{tabular}

Sumber: Hasil Penelitian, 2015

Tabel 4 Struktur musik pada sekuen-sekuen fase komplikasi pertengahan I bagian II

\begin{tabular}{cll}
\hline Dinamika & Tangga nada & \multicolumn{1}{c}{ Teknik } \\
& & \\
\hline Lembut & Slendro $\left(\mathrm{D}^{\#}, \mathrm{~F}^{\#}\right.$, & $\begin{array}{l}\text { Siteran \& Gambang } \\
\text { Suling }\end{array}$ \\
& $\left.\mathrm{G}^{\#}, \mathrm{~A}^{\#}, \mathrm{C}^{\#}\right)$ & $\begin{array}{l}\text { Pengem-bangan } \\
\text { melodi tema I }\end{array}$ \\
\hline Lembut & $\mathrm{Dm}$ & \\
\hline
\end{tabular}

Sumber: Hasil Penelitian, 2015 
Musik Gambang yang digunakan tidak berupa skoring, melainkan sebagai ilustrasi atau penggambaran suasana yang melekat dengan suara Gambang itu sendiri. Penerapan suara Gambang terdapat pada tiga adegan, dua diantaranya adalah adegan tentang rakyat jelata, dan satu adalah adegan tentang perkumpulan Budi Utomo. Pemilihan instrumen Gambang sepertinya didasari oleh lagu Gambang Suling yang memiliki karakter lagu yang mudah disukai oleh siapa saja dan menggambarkan seluruh lapisan masyarakat Yogyakarta termasuk lapisan kaum jelata.

Berikutnya yang termasuk dalam bagian ini adalah sekuen kemajuan Dahlan dalam menyebarkan ajaran-ajarannya yang dibungkus dalam nuansa kebahagiaan. Maka dari itu, Tya menempatkan lagu Lir-ilir sebagai penegas semangat yang dimunculkan pada sekuen ini meskipun hal ini sekaligus merupakan penyebab terjadinya konflik berikutnya, yaitu antara Dahlan dengan para Kyai di Kauman. Konsep penggunaan lagu Lir-ilir memiliki banyak pertimbangan. Selain sebagai penanda tempat asa kelahiran lagu tersebut, Lir-ilir juga memiliki asal-usul dari aspek religi, yakni diciptakan oleh Sunan Kalijaga, tokoh pembesar Islam. Alasan utama yang dipikirkan Tya adalah makna yang terkandung dalam setiap bait lagu tersebut yang intinya mengajak masyarakat untuk "bangun" dan "membuka mata" atas pedoman hidup baru yang dapat mengeluarkan umat dari keterpurukkan.

Fase eksposisi kedua ini merupakan adegan pertama yang menjelaskan sejarah terbentuknya organisasi Islam Muhammadiyah. Pada awal fase, Tya hanya memberikan solo Rebab saat adegan Dahlan menulis salah satu ayat suci Al Quran pada selembar kertas. Solo Rebab juga digunakan sebelumnya pada adegan-adegan pertemuan para Kyai. Dalam hal ini, Tya memberi penjelasan akan makna solo Rebab yang ia gunakan dalam film ini, yaitu mengandung makna tentang kemagisan yang lahir dalam suasana sakral dan gagasangagasan penting dari pemikiran Dahlan yang kemudian dibicarakan dalam sebuah forum. Tya menegaskan bahwa pemilihan instrumen Rebab digunakan dengan pertimbangan harapan nuansa magis dalam pertemuan Kyai tersebut lebih terrepresentasikan (Subiakto, 2018). Serupa dengan solo-solo instrumentasi seperti biola, tembang, dan suling, solo rebab juga memiliki teknik improvisasi dan struktur musikal kolaborasi dengan orkestra ansambel gesek. Dalam akun soundcloud-nya, Tya memberi judul "Kyai’s Argue" untuk musik ini untuk menggambarkan argumentasi para Kyai.

Pada adegan penghancuran Langgar Kidul Dahlan, Tya mengembangkan motif awal Sang Surya dengan teknik penahanan durasi 
pada melodi agar memberikan kesempatan pada penonton untuk mendalami emosi. Cue ini merupakan salah satu dari sepuluh adegan yang dibubuhi dengan permainan solo biola dengan teknik improvisasi. Didiet Violin berperan sebagai pemain biola dengan teknik improvisasi dan Tya mengejakan melodi tema untuknya. Permainan biola pada sekuen-sekuen ini menggunakan teknik pengembangan melodi tema Sang Surya dan improvisasi.

Tya kemudian menggunakan instrumen perkusif berupa timpani dan bel pipa (tubular bell) untuk menegaskan gambaran keputusan akhir yang dilakukan Kyai Penghulu pada Dahlan. Tya juga melakukan beberapa modulasi tangga nada yang bergerak naik dengan harapan membawa emosi penonton ikut terbawa memuncak pada adegan.

Klimaks pertengahan kedua diawali dengan timbulnya respon negatif terhadap apa yang dilakukan Dahlan dari murid-muridnya. Musik yang disajikan dalam adegan ini adalah melodi tema Sang Surya dengan komposisi harpa dan flute sebagai instrumen yang paling dominan dengan iringan instrumentasi gesek. Sekuen ini dimulai dengan dialog Dahlan dengan muridnya, Sudja. Pada musik ilustrasinya, kali ini Tya mengguakan musik karakter Siti Walidah pada tokoh lain. Terkadang Harpa juga bisa digunakan sebagai penanda modernisasi. Seperti yang diketahui, Kyai Ahmad Dahlan membawa pembaharuan, pembaharuan sama dengan modernisasi (Subiakto, 2018). Tya mengembangkan motif pada melodi tema Sang Surya dalam bentuk yang lebih mengalun, menggunakan ketukan 6/8, harmoni pada instrumen harpa dengan teknik arpeggio, dan ditambah dengan instrumen flute. Hal tersebut dilakukan dengan tujuan memunculkan kesan konflik secara lembut, pada konflik antara murid dengan gurunya. Sesekali dinamika musik mengalami kresendo kemudian secara mendadak tiba-tiba berhenti seiring dengan pertanyaan-pertanyaan puncak dari Sudja. Hal tersebut bertujuan untuk mengajak penonton menahan nafasnya sementara pada saat Dahlan mendengar pertanyaan tak terduga dari Sudja.

Pada adegan pertemuan para Kyai berikutnya, Tya mengawali ilustrasi musik dengan solo Rebab lalu kemudian secara perlahan suara instrumen gesek dengan otaf rendah menyusul dengan sesekali muncul tabuhan Timpani. Seperti yang terdapat pada komplikasi sebelumnya berupa pertemuan para Kyai, solo Rebab muncul pada saat adegan-adegan pertemuan sakral yang menimbulkan kemagisan. Lalu, saat Dahlan memberikan gagasan-gagasan penting dalam forum tersebut, musik beralih pada orkestrasi dengan memainkan melodi tema Sang Surya. Ketika situasi memanas, suara Rebab semakin hilang dan diganti dengan progresi harmoni 
instrumen gesek dengan teknik kresendo untuk meningkatkan tensi dramatik adegan klimaks.

Tya menggunakan musik dengan melodi tema kedua pada adegan dialog Dahlan dengan Istrinya. Format instrumen yang digunakan diantaranya Harpa dan instrumentasi alat musik gesek sebagai iringan harmoni. Sedangkan peran melodi utama dimainkan oleh solo biola. Kombinasi format instrumen tersebut merepresentasikan kesan intim yang hadir pada dialog Dahlan dengan Istrinya. Bagian tengah karya ini, nuansa musik berubah menjadi mencekam sekaligus sedih dengan hanya menggunakan nada tunggal ansambel gesek dan improvisasi solo biola. Setelah itu, nuansa musik kembali masuk ke gaya aslinya untuk merepresentasikan solusi yang dilahirkan dari pembicaraan tersebut. Musik ini menggunakan porsi akor minor dan mayor secara merata, yang salah satunya berfungsi untuk memperlihatkan suasana haru ketika Nyai Dahlan tetap konsisten untuk selalu berada di samping suaminya, bagaimanapun keadaanya. Pada birama ketujuh, orkestrasi dari ansambel gesek mulai masuk secara perhalahan dan bertahap berfungsi untuk melapisi harmonisasi pada progresi akor pada cue ini. Untuk menunjukkan akhir yang merepresentasikan kebahagiaan atas solusi yang didapatkan pada pembicaraan tersebut, Tya mengakhiri cue ini dengan jenis akor Mayor.
Klimaks terakhir diawali dengan adegan kontak fisik antara Jema' ah Masjid Besar dengan Jema'ah Langgar Kidul. Tya membuatkan tema melodi baru untuk adegan konflik ini. Selain instrumentasi gesek, Tya menambahkan instrumen Timpani dan Tubular Bell untuk menegaskan kontak fisik yang terjadi, seperti pada pertandingan tinju. Adegan klimaks akhir kedua terkait dengan adegan klimaks akhir yang ketiga, yaitu pada saat penarikan santri Langgar Kidul karena Langgar Kidul dianggap menyimpang dari ajaran Islam Kauman. Adegan penarikan tidak disertai dengan musik, akan tetapi musik untuk adegan perenungan muncul perlahan di akhir adegan dengan maksud menghubungkan kedua adegan yang memiliki keterkaitan seperti yang terdapat pada tabel 5 dan tabel 6.

Tabel 5 Struktur musik pada sekuen-sekuen fase klimaks tahap akhir bagian I

\begin{tabular}{cll}
\hline $\begin{array}{c}\text { Tahap } \\
\text { Klimaks }\end{array}$ & Instrumen & Tempo \& Irama \\
\hline Terakhir & $\begin{array}{l}\text { - Instrumen-tasi } \\
\text { gesek }\end{array}$ & $\begin{array}{l}\text { Agak cepat }( \pm 95 \\
\text { BpM })\end{array}$ \\
(sekuen 1) & - Bel pipa & \\
& - Timpani & \\
& - Simbal & \\
\hline Terakhir & $\begin{array}{l}\text { - Solo biola } \\
\end{array}$ & Rubato \\
(sekuen 2) & Instrumen-tasi & \\
\hline
\end{tabular}

Sumber: Hasil Penelitian, 2015

Tabel 6 Struktur musik pada sekuen-sekuen fase klimaks tahap akhir bagian II

\begin{tabular}{lll}
\hline Dinamika & \multicolumn{1}{c}{$\begin{array}{c}\text { Tangga } \\
\text { nada }\end{array}$} & \multicolumn{1}{c}{ Teknik } \\
\hline - agak keras & $\mathrm{D}^{\#} \mathrm{~m}-\mathrm{G}^{\#} \mathrm{~m}$ & - Pedal point \\
\hline - lembut & $\mathrm{F}^{\#} \mathrm{~m}$ & $\begin{array}{l}\text { - Improvisasi solo } \\
\end{array}$ \\
& & Biola \\
& - Pedal point \\
\hline
\end{tabular}


Sumber: Hasil Penelitian, 2015

Dari penjelasan pada fase klimaks tersebut dapat diambil sebuah interpretasi bahwa Tya banyak melakukan modulasi atau perpindahan tangga nada, permainan dinamika, bahkan dengan tempo bebas dengan maksud mengadukaduk emosi pendengarnya sesuai dengan apa yang dirasakan Dahlan pada film ini. Tya menegaskan sebuah fase (klimaks) dengan menggunakan instrumen Bel Pipa dengan maksud mampu mencerminkan keputusan akhir.

Fase resolusi menggambarkan resolusi atas klimaks yang disampaikan melalui sebuah konflik antara Dahlan dengan murid-muridnya. Repetisi motif dari melodi tema Sang Surya dibalut dengan variasi progresi akor mayor mengiringi dialog ini hingga selesai.

Selanjutnya diperlihatkan gambaran dampak dari hasil dialog tersebut berupa kegiatan-kegiatan sosial yang dilakukan Dahlan serta murid-muridnya. Tya menggunakan lagu tema Sang Surya aransemennya sendiri yang dinyanyikan oleh Rossa. Hingga sekuen ini berakhir, maka berakhir pula musik tersebut. Penjelasan tersebut ditabelkan dalam tabel 7 dan tabel 8 .

Sekuen terus berlanjut pada adegan pernyataan berdirinya organisasi Muhammadiyah yang dibalut dengan instrumentasi gesek yang memainkan perkembangan motif melodi tema Sang Surya.

Tabel 7 Struktur musik pada sekuen-sekuen fase resolusi pertengahan II bagian I

\begin{tabular}{cll}
\hline Tahap Klimaks & \multicolumn{1}{c}{ Instrumen } & $\begin{array}{c}\text { Tempo \& } \\
\text { Irama }\end{array}$ \\
\hline Pertengahan II & $\begin{array}{l}\text { - Instrumen-tas i } \\
\text { gesek }\end{array}$ & Rubato \\
(Sekuen & & \\
pertama) & & \\
\hline Pertengahan II & - Orkestra penuh & $\pm 76 \mathrm{BpM}$ \\
(Sekuen & - Vokal & \\
kedua) & Kor & \\
\hline
\end{tabular}

Sumber: Hasil Penelitian, 2015

Tabel 8 Struktur musik pada sekuen-sekuen fase resolusi pertengahan II bagian II

\begin{tabular}{|c|c|c|}
\hline Dinamika & Tangga nada & Teknik \\
\hline - Sangat lembut & - E Mayor & \\
\hline $\begin{array}{ll}\text { - } & \text { Patriotis } \\
\text { - } & \text { Semangat } \\
\text { - } & \text { Agak keras }\end{array}$ & $-A^{\#}$ minor & $\begin{array}{l}\text { Lagu Sang } \\
\text { Surya }\end{array}$ \\
\hline
\end{tabular}

Sumber: Hasil Penelitian, 2015

Dari penjelasan tersebut maka dapat diambil sebuah interpretasi bahwa terdapat melodi pola dua yang muncul dua kali dengan bentuk yang berbeda.

Film ini diakhiri dengan sekuen berupa sebuah pencapaian yang dialami Ahmad Dahlan. Selain mendapatkan tawaran kerjasama dan penyesalan Kyai Penghulu, sekuen ini menyimpulkan oerjuangan-perjuangan yang dilakukan Ahmad Dahlan dalam menyampaikan ajaran-ajaran Islam melalui cara berpikirnya. Fase konklusi tersebut diawali dengan suara lonceng yang menandakan akhir sebuah konflik. Musik pada adegan-adegan fase konklusi ini menggunakan tangga nada juga akor-akor 
berjenis mayor. Akor mayor memperlihatkan keadaan dan rasa bahagia. Hal tersebut memperlihatkan kesesuaian penggunaan akor mayor pada adegan konklusi yang diberikan Tya Subiakto untuk menggambarkan sebuah kebahagiaan dan kemenangan yang dirasakan Ahmad Dahlan masa itu. Musik pada adeganadegan ini juga menggunakan instrumen bel sebagai penanda akhir konflik, seperti halnya ketika waktu babak habis pada sebuah pertandingan tinju. Bentuk lagu pada sekuen pembuka kembali dimunculkan oleh Tya Subiakto dengan struktur instrumen gesek, tiup, perkusif, hingga kolaborasi dengan lantunan ayat suci Al-Quran. Musik film yang berhubungan dengan lagu Sang Surya pada adegan-adegan ini menjadi penutup film Sang Pencerah.

Analisis berdasarkan pembagianpembagian struktur dramatik membantu peneliti melihat perjalanan musik secara keseluruhan film. Berdasarkan hasil analisis, peneliti menuimpulkan perubahan musik seperti pada gambar 3 .

Untuk melihat ciri khas dan karakter musik Film Sang Pencerah, peneliti melakukan analisis sederhana terhadap karya musik film Tya yang lain, film Ayat-ayat Cinta dan film Rudy Habibie. Secara keseluruhan, bagianbagian dalam tubuh musik film Ayat-ayat

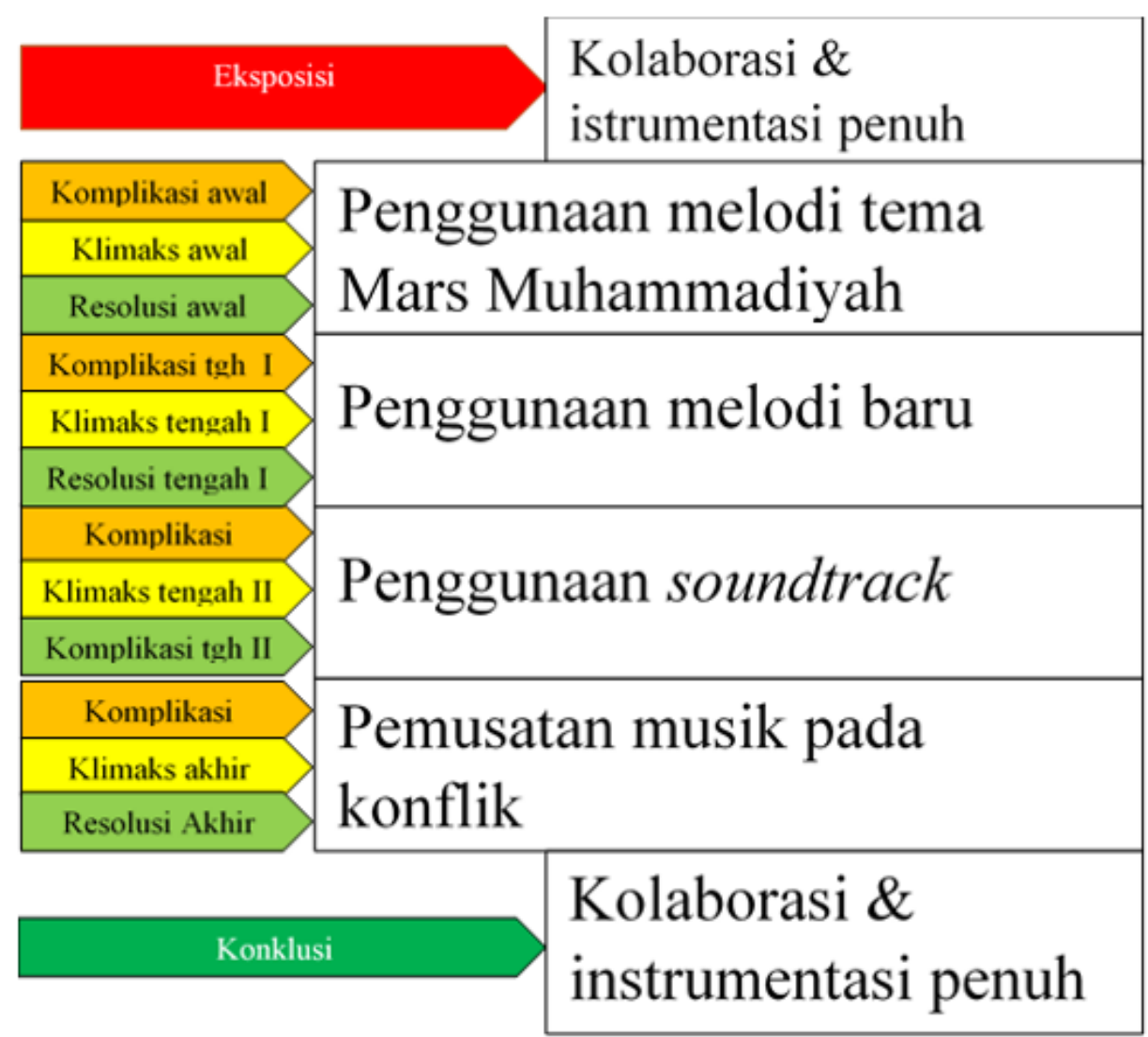

Sumber: Pribadi, 2018

Gambar 3 Struktur musik film Sang Pencerah secara keseluruhan 
Cinta memiliki beberapa kesamaan dengan musik film Sang Pencerah, kesamaan tersebut meliputi penggunaan instrumen solo Biola dan penggunaan melodi tema yang diambil dari lagu tema (Ayat-ayat Cinta - Rossa). Kesamaan yang lain terletak pada penggunaan nada rendah tunggal dengan durasi panjang, serta kolaborasi dengan lantunan ayat suci Al-Quran dengan komposisi instrumen orkestra sebagai pelapis. Terdapat juga beberapa kesamaan dari kesimpulan perbandingan dengan musik film Sang Pencerah, seperti nada rendah tunggal dengan durasi panjang, komposisi orkestra, penggunaan suara bel pipa untuk konteks konfrontasi, solo instrumen, dan penggunaan melodi tema yang diambil dari lagu tema. Dari hasil analisis sederhana tersebut, peneliti menyimpulkan bahwa ciri khas dan karakter pada musik film Sang Pencerah yang diciptakan Tya Subiakto adalah penggunaan instrumen orkestra, penggunaan nada rendah tunggal dengan durasi panjang, penggunaan solo instrumen, penggunaan melodi tema dari lagu tema, penggunaan suara bel pipa, dan kolaborasi lantunan ayat suci Al-Quran.

\section{SIMPULAN}

Terjadinya perilaku kreatif pada diri Tya Subiakto adalah karena kreativitas dalam dirinya muncul karena keinginan yang tidak terpenuhi sehingga mendorong munculnya ide-ide untuk berkreasi. Mekanisme pertahanan berhasil mengalihkan dorongan ayahnya mengarahkan Tya menjadi seorang psikolog. Tya bekerja keras menyalurkan kreativitasnya pada musik film untuk mewujudkan tekadnya menjadi seorang komponis musik film Sang Pencerah. Kemampuan Tya mengolah orkestrasi dan atribut berbau budaya musik Barat menjadi karakter pada setiap karya-karya musik film yang Ia garap.

Prosedur komposisi yang ia lakukan serupa dengan prosedur yang dilakukan komponis Barat yang menjadikan orkestrasi sebagai bingkai utama musik dan sentuhan musik tradisional untuk fungsi naratif dari musik. Berdasarkan hubungan analisis karya dan biografi Tya Subiakto, dapat disimpulkan bahwa Tya tidak hanya mengintrojeksi sosok John Williams (komponis musik film) ke dalam dirinya, tapi Tya juga mempelajari atributatribut musik barat hingga ke estetika terdalam pada referensi-referensi kreatifnya. Hal tersebut tercermin dalam film Sang Pencerah yang menjadikan orkestrasi sebagai instrumen pokok dan dibalut dengan musik tradisional sebagai penguat dalam fungsi naratifnya. Dengan demikian, dapat dikatakan bahwa masa kecil Tya mempengaruhi kreativitasnya dengan menjadikan orkestrasi sebagai instrumen pokok dalam musik film Sang Pencerah.

Secara filosofis, musik film memiliki 
keunikan tersendiri seperti selalu melekat pada sebuah kejadian, tempat, dan waktu menjadi hal yang menarik untuk diteliti. Penelitian mengenai pengaruh musik film pada reaksi penonton masih perlu diperdalam dalam kesesuaiannya dengan keilmuan dan budaya lokal. Kajian tentang aspek naratif, afektif, maupun indikatif musik film terhadap psikologi menjadi topik yang tidak kalah menarik untuk dikaji. Juga, musik yang terdapat dalam cuplikan film (trailer) tentang bagaimana musik dengan durasi pendek bisa merangkum keseluruhan konten film, menjadi hal yang menarik untuk dibahas.

\section{DAFTAR PUSTAKA}

Anggana, Y. (2018). Wawancara dengan Yuga Anggana. Bandung-Lombok.

Beveridge, S., \& Knox, D. (2018). Popular music and the role of vocal melody in perceived emotion. Psychology of Music, 46(3), 411-423. https://doi. org/10.1177/0305735617713834

C. Noer, E. (2018). Wawancara VIA Whatsapp. Bandung-Jakarta.

Freud, S. (2005). A general introduction to psychoanalysis. In $A$ general introduction to psychoanalysis. https://doi. org/10.1037/10667-000

Green, G., \& Jones, G. T. (1974). Music Theory. Notes. https://doi.org/10.2307/897141

Hevner, K. (1935). The Affective Character of the Major and Minor Modes in Music. The American Journal of Psychology. https:// doi.org/10.2307/1416710

Hidayat, D., Rosidah, Z., Retnasary, M., \& Suhadi, M. (2019). Nilai-nilai kearifan lokal pada unsur naratif dan sinematik film Jelita Sejuba. ProTVF. https://doi. org/10.24198/ptvf.v3i2.21264

Indri, D. (2012). Musik film di indonesia belum dianggap penting. Retrieved July 21, 2017, from http://deeanindric.blogspot. com/2012/11/musik-film-di-indonesiabelum-dianggap.html

Juslin, Barradas, \& Eerola. (2015). From Sound to Significance: Exploring the Mechanisms Underlying Emotional Reactions to Music. The American Journal of Psychology, 128(3), 281. https://doi.org/10.5406/ amerjpsyc.128.3.0281

Kim, J., Strohbach, C. A., \& Wedell, D. H. (2019). Effects of manipulating the tempo of popular songs on behavioral and physiological responses. Psychology of Music, 47(3). https://doi. org $/ 10.1177 / 0305735618754688$

Kurniawati, L. (2019). Implikasi standar program siaran pada tayangan edukasi dan artistik TVRI Jawa Barat. ProTVF. https:// doi.org/10.24198/ptvf.v3i2.23008

Liu, Y., Zhao, Y., \& Hua, K. A. (2015). What Strikes the Strings of Your Heart? - Feature Mining for Music Emotion Analysis. IEEE Transactions on Affective Computing. https://doi.org/10.1109/ TAFFC.2015.2396151

Matthews, J. B. (1879). The Theatres of Paris. The Art Journal (1875-1887). https://doi. org/10.2307/20569403

Palmer, S., \& Yorke, E. (2012). “The Technique of Film Music" (Roger Manvell and John Huntley; 1957) [Books Reviewed]. Journal of the SMPTE. https://doi.org/10.5594/ j14473

Pratista, H. (2017). Memahami film (2nd ed.). Retrieved from https://montasefilm.com/ buku-memahami-film-edisi-2-telah-terbit/ 
Setiawan, E. (2017). Musik Film: Antara

Emosi, Teknologi, dan Kreativitasnya. Retrieved March 15, 2017, from https://compusiciannews.com/MusikFilm-Antara-Emosi-Teknologi-danKreativitasnya/

Subiakto, T. (2018). Wawancara Tya Subiakto.

Bandung-Jakarta.

Swaminathan, S., \& Schellenberg, E. G. (2015). Current Emotion Research in Music Psychology. Emotion Review, 7(2), 189-197. https://doi. org/10.1177/1754073914558282

Symphonic Library, V. (2017). Harps Sound Characteristics. Retrieved September 9, 2017, from https://www.vsl.co.at/en/Harp/ Sound Characteristics

Wikagoe, B. (2018). Wawancara dengan Bucky Wikagoe. Retrieved from https:// drive.google.com/open?id=1LGNhTD2PpzRk0zDVSP9qhJvBmS2bJeD

Zulkarnain.(2013).KreativitasDalamPerspektif Teori Kepribadian Sigmund Freud Dan Implikasinya Dalam Pendidikan. 146-162. 